WORKING PAPERS

Trade Policy

Country Economics Department

The World Bank

October 1990

WPS 516

\title{
International Capital Mobility and the Costs of U.S. Import Restraints
}

\author{
Jaime de Melo \\ and \\ David Roland-Holst
}

Model estimates indicate the practical importance of capital mobility - and terms-of-trade and rental adjustments - in determining the ultimate welfare effects of import restraints. 


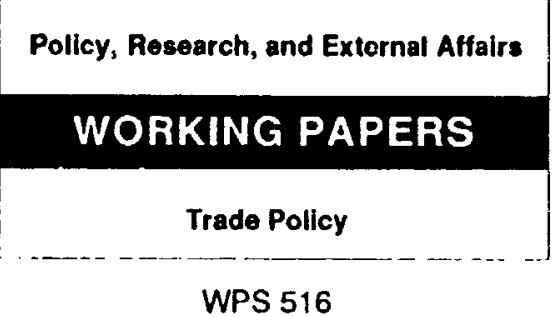

This paper - a product of the Trade Policy Division, Country Economics Department - is part of a larger effor in PRE to understand the effects of trade policy on industrial efficiency. Copies are available free from the World Bank, 1818 H Strect NW, Washington DC 20433. Pleasc contact Sheila Fallon, room N10-017, extension 37947 (24 pages).

De Mclo and Roland-Holst evaluate the gencralequilibrium welfare effects of tariffs, quotas, and voluntary export restraints under different assumptions about international capital mobility.

They show analytically that when the induced effects of terms of trade and rental rates are considered, the qualitative influence of capital mobility on the costs of protection cannot be ascertained unambiguously. (Thus the importance of answering this question empirically.)

They use a computable general equilibrium model of the United States to estimate these effects empirically. These estimates indicate the practical importance of capital mobility - and of terms-of-trade and rental adjustments - in determining the ultimate welfare effects of import restraints.

The PRE Working Paper Series disseminates the findings of work under way in the Bank's Policy. Research, and External Affairs Complex. An objective of the series is to get these findings out quickly, even if presentations are less than fully polished. The findings, interpretations, and conclusions in these papers do not necessarily represent official Bank policy. 
International Capital Mobility and the Costs
of Import Restraints

\author{
by \\ Jaime de Melo \\ and \\ David Roland-Holst
}

\title{
Table of Contents
}

1. Introduction 1

2. Qualitative Analysis of Import Restraints 2

3. An Pplication to the Welfare Effects of U.S. 10 Import Restrictions

4. Conclusions 16

$\begin{array}{ll}\text { Footnotes } & 17\end{array}$

$\begin{array}{ll}\text { References } & 18\end{array}$

$\begin{array}{ll}\text { Appendix } & 19\end{array}$

A1. Model Outline 19

A2. Benchmarking to $1984 \quad 20$ 


\section{Introduction}

In a series of recent papers, Neary and others have established the importance of trade in factor services, especially capital, in determining the welfare effects of import restrictions by tariffs, QRs, and VERs. I/ In the absence of induced terms-of-trade changes and rental rate effects, Neary (1988) demonstrates that international capital mobility raises the costs of tariff protection and lowers that of QRs and VERs. In this paper, we examine more systematically the impact of international capital mobility on the welfare effects of import protection by tariff, QRs, and VERs. Generalizing the work of Neary and others to take explicit account of induced terms-of-trade and rental rate effects, we demonstrate that the qualitative influence of capital mobility on the costs of protection cannot be ascertained unambiguously. This reveals the importance, emphasized by Dixit (1987) among others, of deciding this question on empirical grounds. We then simulate the aggregate welfare effects of import restraints for the U.S. under different assumptions about international capital mobility, and the influence of the size of the U.S. in world markets.

The paper is organized as sollows: Section 2 sets up an analytical model that indicates the general links between international capital mobility and the welfare effects of different forms of import restraint. Section 3 reports on the estimated welfare impact of international capital mobility on the welfare effects of U.S. import protection. Conclusions follow in section 4. 
2. Qualitative Analysis of Import Restraints.

We develop a general trade model to analyze the qualitative effects of alternative forms of protection with and without capital mobility. The purpose is to show how the welfare costs of various forms of protection are affected by international capital mobility in a general model with terms of trade and rental effects. To this end, consider an economy where tradables are produced by atomistic firms in perfect competition, demand and supply functions are continuous and differentiable, and trade policy changes do not affect the pattern of trade specialization. $\underline{2}$ I

Preferences for a representative consumer are sumarized by an expenditure function:

$$
e(p, u)=Y
$$

where $p$ is a vector of domestic prices and $\dot{u}$ is a well-behaved utility function. Domestic income, $Y$, is then given by GDP plus tariff revenue, net of expatriated rentals, i.e.

$$
Y=g(p, 1+k)+(1-\theta) t \cdot \hat{M}-r k-\bar{b}
$$

where $g$ is the continuously differentiable GDP function, $M$ and $t$ are vectors of imports and tariffs, $\hat{\boldsymbol{T}}$ is a diagonal matrix of world prices for imports, $\bar{b}$ is an exogenous net transfer unrelated to trade restrictions, and $r$ is the rental rate. Tariff rates, $t$, are exogenous policy parameters when imports are not constrained, but when imports are constrained, $t$ represents the endogenous premium rate on the constrained imports. The 
parameter $0<\theta<1$ measures the share of revenues (rents) accruing to foreigners. For simplicity, assume that the share is zero for tariffs and QRs, unity for VERs. By choice of units, the exogenously fixed stock of domestically-owned capital is set equal to unity, and the foreign-owned capital stock, net of domestic capital ownership abroad, used in domestic production is denoted by $k$. Using standerd duality theory, the equilibrium rental rate and import levels rental rate are given by:

$$
\mathbf{r}=8 \mathrm{k}(\mathrm{p}, 1+\mathrm{k})
$$

and

$$
M=e_{p}(p, u)-g_{p}(p, 1+k)
$$

where lower case subscripts denote partial differentiation. To $c$ in the welfare effects of a change in trade policy, equate (2.1) and (2.2), totally differentiate and substitute (2.3). In the remainder of the discussion, we assume there are no transfers unrelated to trade restrict-

ions, i.e., $d \bar{b}=0$. Then, the resulting expression for the change in welfare, $d y=e_{u}(p, u) d u$, which is the change in aggregate utility measured in numeraire units, is given by:

$$
d y=(1-\theta) t^{\prime} d m-\theta M^{\prime} d t-M^{\prime}[I-(1-\theta) \hat{t}] d x-k d r
$$

where a prime denotes a transpose, I is the identity matrix, a caret denotes a diagonal matrix, distorted domestic prices have been expressed in terms of tariffs $\rightarrow$ world prices $(d p=d x+d t)$, and world prices have 
been set equal to unity. The first wo terms of (2.5) indicate that, in the presence of a distortion, any increase in imports will be welfare improving. However, the third tem measures the welfare loss from purchasing imports at rising world prices. Note that the increasing cost of imports is itself offset by rising domestic tariff revenues (provided that $\theta<1$ ). In the case of inmobile capital, the last term denotes the effect of changing endugenous rents on income repatriated to foreigners. On the other hand, when capital is internationally mobile, we will assume perfect capital mobility (i.e. dr=0) and $k$ endogenous.

To evaluate the role of capital mobility on the effects of import protection, consider first the case of protection by tariffs (i.e., $\theta=0$ ). With immobile capital, the welfare change induced by a tari $f$ is then given by:

$$
d y=t \cdot d M^{\prime}-M^{\prime}(I-\hat{t}) \pi_{m} d M-k d r
$$

where $\pi_{m}$ denotes a jacobian matrix of terms-of-trade effects induced by trade flows. In the case of a tariff and immobile capital both $\mathrm{dr}$ and $\mathrm{dM}$ are endogenous and can be obtained from (2.3) and $(2.4)$, respectively. The change in the rental rate is given by:

$$
\begin{aligned}
d r & =g_{k p} d p+g_{k k} d k \\
& =g_{k p} d t+g_{k p} \pi_{\mathbb{m}} d M
\end{aligned}
$$

and the change in imports by

$$
\begin{aligned}
d M & =e_{p p} d p+e_{p u} d u-8_{p p} d p-8_{p k} d k \\
& =-\left(8 p p-e_{p p}\right) d p+e_{p u} d u \\
& =-5 d t-5 \pi_{m} d M+x_{y} d y \\
& =-\left(I+S \pi_{m}\right)-1\left[S d t-x_{y} d y\right]
\end{aligned}
$$


In equ.librium, the change in imports is inversely related to the price response of excess domestic supply (the first term in brackets), and negatively related to the income-induced change in demand, $x_{y}$ dy, where $x_{y}$ denotes the income elasticity of demand in numéraire units.

Combining expressions $(2.6),(2.7)$, and $(2.8)$ leads to a reducedform for the aggregate welfare effect of a tariff when capital is immobile, i.e..

$$
d y=-\left(1-a \cdot x_{y}\right)-1\left(a \cdot s+k g_{k p}\right) d t
$$

with net tariff income effect

$$
a^{\prime}=\left(t^{\prime}-\left[M^{\prime}(I-t)+k g_{k p}\right] \pi_{m}\right\}\left(I+s \pi_{m}\right)^{-1}
$$

The last expression indisates how induced terms-of-trade effects may offset distortionary welfare costs. sue influence of rental rate changes, $\mathrm{kgkp}_{\mathrm{kp}}=$ $k r_{p}$, depends upon the overall capital intensity of tradables and cannot generally be signed.

Consider now the case when capital is internationally mobile. Then expression (2.7) takes the form

$$
d \tau=g_{k p} d p+8 k k d k=0
$$

and substituting for dk from (2.11) into (2.8) ylelds

$$
\begin{aligned}
d M & =-\left(g_{p p}-g_{p k} g_{k k}^{-1} g_{k p}-e_{p p}\right) d p+x y_{y}^{d} \\
& =-\tilde{s} d t-\tilde{s} \pi_{m} d y+x_{y} d y
\end{aligned}
$$




$$
=-\left(I+\tilde{S} \pi_{m}\right)^{-1}\left[\tilde{S} d t-x_{y} d y\right]
$$

using a tilde to denote a corresponding expressinn under internntional capital mobility. We now have the following expression for the welfare effect of a tariff change:

$$
\tilde{d y}=-\left(1-\tilde{a} \cdot x_{y}\right)^{-1} a \cdot \tilde{s} d t
$$

where

$$
\tilde{a}^{\prime}=\left\{t^{\prime}-M^{\prime}(I-t) \pi_{m}\right\}\left(I+\tilde{s} \pi_{m}\right)^{-1}
$$

Direct comparison of expressions (2.9) and (2.13) yields no general conclusions. Neary (1988) and others have observed that $|\tilde{s}|>|s|$ because of the Le Chatelier Principle and the Envelope Theorem. Access to competitive international capital markets (i.e., assuming that $r$ is fixed) raises domestic supply elasticities, increasing the quantity response to normal trade distortions. This drives the economy farther from free trade. However, we show that this effect will be offset by induced terms-of-trade and rental rate changes. The relative importance of each effect will depend upon the factor intensities of all tradable goods, and on the size of the economy in world markets. Assuming away terms of trade effects, i.e. $a^{*}=\tilde{a}^{\prime}=t^{\prime}$, the difference between tariff-induced welfare effects, with and without capital mobility, becomes

$$
\begin{aligned}
& \left.d \tilde{y}-d y=\left(1-t \cdot x_{y}\right)^{-1}[t \cdot \tilde{s}-s)-k_{g_{k p}}\right] d t \\
& =\left(1-t^{\prime} x_{y}\right)^{-1}\left[-t^{\prime} g_{p k} g_{k k}{ }^{-1} g_{k p}-k g_{k p}\right] d t
\end{aligned}
$$


The sign of the first term in bracket; is positive, since $8 \mathrm{kk}^{-1}<0$, but the second term is still indeterminate. Neary and Ruane (1983, p. 576) assume that 8kp $=0$, - rile Neary (1988, fn. p. 729) assumes $k=0$. The significance of foreigi-owned capital and of the protection-induced change in the value of paynents to foreign owners of capital io an issue that must be settled on empirical grounds. $3 /$ The results above emphasize the importance of estimating these effacts in countries with high levels of foreign investment.

The role of terms-of-trade effects is more complex, but nonetheless intuitive. These will partially or completely offset the distortionary costs of tariffs, leading in the latter case :0 welfare gains. If we omit rental rate effects, however, then

$$
d \tilde{y}-d y=-f(\tilde{a}) \cdot \tilde{s}+f(a) \cdot s
$$

where $f_{a}>0$. Since $\tilde{S}>S$, then $\tilde{a}>a$ would mean that capital mobility increases the welfare effects (cost or benefit) of tariffs, as implied by Neary's results. A sufficient condition for this case to obtain would be that tradables have no cross terms-of-trade effects ( $\pi_{m}$ is diagonal and all nonzero elehents are negative). However, empirical results below suggest that cross terms-of-trade effects are not likely to be negligible, at least for the U.S.

Turn now to the welfare effect of a quota on imports $(\theta=0)$. Under competitive conditions, one can establish a first-order equivalence with a tariff since:

$$
d y=\left\{t^{\prime}-\left[M^{\prime}(I-t)+k_{k p}\right] \pi_{m}\right\} d M
$$


when capital is immobile and

$$
d \tilde{y}=\left[t^{\prime}-M^{\prime}(I-\hat{t}) \pi\right] d M
$$

when capital is internationally mobile. Since dM is exogenous, there is no first-order role for irternationally mojile capital, and the difference $d \tilde{y}-d y=k k_{k p} \pi_{m} d M$ depends upon domestic rental rate adjustments and induced terms-of-trade effects.

Second-order quota effects do admit a role for capital mobility. To evaluate these, expand the Taylor series

$$
d y=y_{m} d M+J / 2 d M^{\prime} y_{\operatorname{mm}} d M
$$

where $y_{m}$ is obtained from $(2.17)$ and $(2.18)$ and $y_{m m}=t_{m}-B$, represents the role of first-order domestic price (now endogenous import premia $t$ ) adjustments, $t_{m}$, and $B$, the second-order terms-of-trade effects. We assume the latter to be negligible and solve for the former in each case. When capital is immobile, $t_{m}$ is obtained by substituting the exogenous quota adjustment dM from (2.8) into (2.6), and algebraic manipulation yields

$$
\begin{aligned}
t_{m} & =-\left(S+x_{y} k g_{k p}\right)^{-1}\left\{I-x_{y}\left[t \cdot-M \cdot(I-\hat{t}) \pi_{m}\right]\right\}-\pi_{m} \\
& =p_{m}-\pi_{m}
\end{aligned}
$$

The corresponasng expression for mobil capital is obtained from (2.6) and (2.12) as

$$
\begin{aligned}
\tilde{t}_{m} & =-\tilde{s}^{-1}\left\{I-x_{y}\left[t \cdot-M^{*}(I-\hat{t}) \tilde{m}_{m}\right]\right\}-\pi_{m} \\
& =\tilde{p}_{m}-\pi_{m}
\end{aligned}
$$

and the difference in price effects due to capital mobility can be represented by the determinant 


$$
\begin{aligned}
& \left|\tilde{t}_{m}-t_{m}\right|=\left|\tilde{p}_{m}-p_{m}\right| \\
& =-\left|\left[\tilde{s}^{-1}-\left(s+x_{y} k g_{k p}\right)^{-1}\right]\right| \cdot\left|\left\{I-x_{y}\left[t \cdot M \cdot(I-t) \pi_{m}\right]\right\}\right|
\end{aligned}
$$

Again, the result depends upon the relative factor intensity of all tradables and induced terms-of-trade effects. As Neary (1988) and Neary and Ruane (1988) emphasize, the first term in brackets above is negative because of Le Chatelier effects. As was argued intultively above, access to competitive international capital markets increases domestic supply elasticities, thus reducing required price adjustments to exogenously fixed quanticy adjustmel.cs. In Neary and Ruane (1988) and Neary (1988), kgkp = 0 and $\pi_{m}=0$, so the first determinant above is negative, the second is unity. Ignoring only terms-of-trade effects, purely capital-intensive tradables would magnify the effect Neary predicts (capital mobility lowers the cost of quotas), while labor-intensive tradables would counteract it. The same argument applies when $\pi_{m}$ is nonzero. Thus, in general, expression (2.22) cannot be reliably signed, and recourse to empirical estimation is necessary.

When imports are subject to VER restraints, the cost of protection with immobile capital is $(\theta=1)$.

$$
\begin{aligned}
d y & =M^{\prime} d t-M^{\prime} d \pi-k d r \\
& =-M^{\prime} d p-k g_{k p} d \pi \\
& =-\left(M^{\prime} P_{m}+k g k p \pi_{m}\right) d M
\end{aligned}
$$




$$
d \tilde{y}=-M \cdot p_{m} d M
$$

and capital mobility plays a more direct, but equally inconclusive, role. Assuming away terms-of-trade and rental effects, one obtains Neary's (1988) result that (2.23) is negative and that the welfare effects of VERs are reduced because of capital mobility. Again, this is an issue to be settled empirically.

We have shown that terms-of-trade and rental rate valuation effects are sufficient to prevent one from signing the effects of 1. ternational capital mobility on the welfare costs of tariffs, QRs, and VERs. Terms-of-trade and rental effects are unlikely to be negligible, at least for a number of industrialized countries which have sizeable worldwide market shares. Thus we examine further the issue with a numerical application to the U.S. economy, evaluating the costs of protection with and without capital mobility for the year 1984.

\section{An Application to the Welfare Effects of U.S. Import Restrictions}

This section evaluates the aggregate welfare costs to the U.S. of QRs in autos, textiles and steel and of tariffs, using a static six-sector computable general equilibrium (CGE) model. $4 /$ The model is calibrated to 1984 data and is more thoroughly discussed in the appendix. Two forms of trade restriction are modelled: tariff protection with tax collection returned to the representative consumer; and $Q R$ protection. Two assumptions are made with respect to factor mobility: (1) no capital mobility, in which case capitai owned by domestic and foreign residents are 
the welfare costs of protection would be eliminated if the us could capture the premia by, for example, auctioning import licenses to importers.

Consider now the effects of induced terms-of-trade changes, looking first at the results in column 1 for immobile capital. An optimal level of $Q R$ (or tariff) protection can, in the absence of retaliation, improve national welfare. For the midsize economy, the optimal level of protection will be lower than for the large economy, but as is indicated by the estimates of the distortionary costs of QRs, it is still higher than the level of protection prevailing in 1984. Thus the distortionary costs of QRs are cut in half for the midsize economy case and become negative only in the large economy case. Observe now that the estimate of the premium component cost of VERs is largely unaffected by terms-of-trade changes. The reason is that we have assumed the same degree of monopoly and monopsony power in exports and imports. Hence the terms-of-trade losses in expenditures on imports are compensated by terms-of-trade gains on a lower volume of exports. Note also that, for the midsize economy case, the U.S. would be likely to see its welfare reduced by a unilateral tariff reduction. Of course, more detailed econometric evidence or export demand and import supply elasticities would be necessary to have confidence in this result, but it is nonetheless suggestive of the dilema facing a large country when it contemplates a unilateral reduction in protection.

Note from the discussion of expression (2.15) that the Le Chatelier effect influences costs and benefits symmetrically. Now the induced terms-of-trade reverse the welfare effects of tariffs, but capital mobility reduces the magnitude of the 1088 from tariff liberalization as it 
does the gain under fixed world prices. The effects on premia capture and full liberalization are also reversed.

The large economy variant gives a more extreme example of termsof-trade effects. Now the distortionary costs of QRs are also negative because of the induced terms-of-trade losses and capital mobility attenuates losses from removing QRs as well as the losses from removing tariffs.

To sumarize, although none of the uniform elasticity scenarios described here will correspond exactly to the degree of U.S. market power in the world economy, it is apparent from the midsize economy results that induced terms-of-trade effects have a strong influence on the welfare effects of protection, and particularly on the role of capital mobility in determining those effects. The simulations also pointed out to the quantitative relevance of expatriated rental incone effects.

\section{Conclusions}

This paper has extended previous analytical work on the role of international capital mobility in determining the welfare effects of various forms of import protection. Taking into account induced terms-oftrade and rental rate effects, we showed that the effect of capital mobility on welfare cannot be ascertained qualitatively. This indeterminacy led us to present a set of empirical results obtained from a CGE model of the U.S. These results confirm the importance of terms-oftrade and rental effects in determining the ultimate effects of capital mobility on the welfare costs of import restraints for an economy integrated into the world capital markets. The simulations also illustrated the importance of second-best effects in the evaluation of the costs of protection when there is international capital mobility. 


\section{Foonotes}

1/ See for example, Neary and Ruane (1988), Neary (1988).

2/ The presentation follows closely Neary (1988). Wherever possible, our notation is the same as his.

3/ For example, in 1984 the foreign-owned share of the U.S. net capital stock was 1.47 and by 1988 this percent had risen six-fold. During the same period, the trade-weighted U.S. average tariff rate was $3.4 \mathrm{Z}$ on imports representing 5.67 of gross output.

4/ The model is an extension of the model presented in de Melo and Tarr (1990) to include capital mobility. 


\section{References}

Brecher, R. and C. Diaz-Alejandro, 1977, "Tariffs, Foreign Capital and Immiserizing Growth" Journal of International Economics, 7:317-22.

Dixit, A. K., 1987, "Strategic Aspects of Trade Policy," in Truman Bewley (ed.), Advances in Economic Theory: Fifth World Congress, Econometric Society Monographs, Cambridge University Press, Cambridge.

Dixit, A. K. and V. Norman, 1980, Theory of International Trade, Cambridge University Press, Cambridge.

Elliot, K., J. Schott and W. Takacs, 1987, Auction Quotas and U.S. Trade Policy. Institute for International Econonics, Washington, D.C.

Jones, R., 1967, "International capital movements and the theory of tariffs and trade," Quarterly Journal of Economics, 81, 1-38.

Jones, R., 1984, "Protection and the Harmful Effects of Endogenous Capital Flows," Economic Letters, 15, 325-30.

Melo, J. de and D. Tarr, 1990, "Welfare Costs of U.S. Quotas in Textiles, Steel and Autos" Review of Economics and Statistics,

Melo, J. de and D. Roland-Holst, 1989, "Structural Adjustment to Import Restrictions When Factor Services are Tradable," paper presented to the N.B.E.R. workshop on Applied General Equilibrium Analyses, San Diego, September.

Melo. J. de and S. Robinson, 1986, "Product Differentiation and Trade Dependence of the Domestic Price Systen in Computable General Equilibrium Trade Models" in T. Peeters et al. eds., International Trade and Exchange Rates in the Late Eighties, North Holland, Ams terdam.

Neary, J. P., 1985, "International Factor Mobility, Minimum Wage Rates and Factor Price Equalization: A Synthesis," Quarterly Journal of Economics, $100,551-70$.

Neary, J. P., 1988, "Tariffs, quotas, and voluntary export restraints with and without internationslly mobile capital, "Canadian Journal of Economics, 11, 714-735.

Neary, J. P. and F. Ruane, 1988, "International Capital Mobility, Shadow Prices, and the Cost of Protection," International Economic Review. 
Append1x

This appendix describes the structure and functional forms of the model used for the simulations reported in section 3 and the benchmarking to 1984 US data.

\section{Al. Model Outline}

Table Al presents the structure and functional forms of the static six-sector model used for the simulations. To save on notation, a onesector version of the model is presented here. This helps focus the presentation on the treatment of different forms of protection and on assumptions about capital mobility. As in section 2, the model aggregates all components of finsl demand into consumption demand and the government sector returns all tax revenue (entirely due to tariffs) to the representative consumer. Hence, the economy only has trade distortions so that changes in welface are entirely accounted for by changes in trade policy under each one of the model closures. Production takes place under perfect competition.

The welfare measure is the expenditure function associated with the LES utility function (eq. A.1) from which are derived labor supply, L. (eq. A.4) and composite consumption expenditures, C, (eq. A.9). Technology is described by CES functions for value-added (eq. A.2) and Leontief functions between intermediates (as a whole) and value-added, as well as within intermediates (eq. A.3). However, within each sector, demand is a CES function between domestically and foreign-produced goods (eqs. A.7 and A.8). Thus, the same elasticity of substitution between domestic and imported goods is assumed by end-use. Finally, export supply is given by a 
CET function (eqs. A.11 and A.12). The assumption of product differentiation on the export side and on the import side rules out trade specialization in response to changes in trade policy.

\section{A2. Benchmarking to 1984}

Table A2 shows that the three sectors subject to import restraints are import-competing (low export-to-supply ratios and relatively high import-supply ratios) whereas the other two traded sectors export a substantial share of domestic production. This has implications for the resource pulls of trade policy changes in a model with product differentiation. In particular, an increase in protection in the "primary" or "other tradable" sectors will have, other things being equal, a smaller effect on resource pulls because of the possibility to divert export sales to the domestic market.

Ad valorem tariff rates appear in column 7 . Note that these are applied on the premium-inclusive price of imports. The premium rate for textiles and vehicles is given in column 7. As explained in de Melo and Tarr (1989, chp. 4), these premia rates are conservative estimates of the premia due to quantitative restrictions in those sectors. The last four columns give the values assumed for the various elasticities describing demand and supply response.

Though not indicated in the table, the model was calibrated to the (exogenous) current account deficit of $\$ 104$ billion in 1984 . Finally, note that because the model is calibrated to 1984 , there is no premium rate on steel imports. As discussed in the text, rationing steel imports gives rise to a 77 premium on steel imports. 
Table A1: A ONE SECTOR CGE MODEL

Expenditure Function (EXP)

$$
\operatorname{EXP}=\operatorname{LES}(P, Y)
$$

Technology

$$
\begin{aligned}
& X=\operatorname{MIN}\left\{\frac{V}{A}, \operatorname{CES}\left(L, K, \sigma_{p}\right)\right\} \\
& V=A X
\end{aligned}
$$

Factor Supplies

$$
\begin{aligned}
& L=\overline{L S} \\
& K=\overline{K D}+K M
\end{aligned}
$$

Factor Demands

$$
L / K=\operatorname{CES}_{p}(r / w)^{\sigma_{p}}
$$

Domestic Demand and Allocation of Traded Goods

$$
\begin{aligned}
& Q=\operatorname{CES}\left(D, M ; \sigma_{m}\right) \\
& D / M=\operatorname{CES}_{\mathfrak{m}}(P M V / P D)^{\sigma_{m}} \\
& C=\operatorname{LES}(Q, Y) \\
& D=V D+C D ; M=C M+V M \\
& X^{S}=\operatorname{CET}\left(D, E ; \sigma_{e}\right) \\
& D / E=C E T_{e}(P D / P E)^{\sigma_{e}}
\end{aligned}
$$

Domestic Goods Market Equilibrium

$$
X^{3}=D
$$


Table AI (continued)

Incoms and Government Revenue.

$$
\begin{aligned}
& Y=\mathrm{WL}+\mathrm{r \overline {KD }}+\mathrm{GR}-\overline{\mathrm{b}} \cdot \mathrm{ER}+(1-\theta)(\lambda \cdot \mathrm{M} \cdot \mathrm{PM}) \mathrm{ER} \\
& \mathrm{GR}=\pi \cdot \mathrm{M} \cdot \mathrm{t} \cdot \mathrm{ER}
\end{aligned}
$$

Trade Balance Constraint

$$
\pi(M-E)=\bar{b}-\operatorname{cM}-\theta(\lambda \cdot M \cdot P M) E R
$$

Foreign-Traded Goods Prices

$$
\begin{aligned}
& \mathrm{PE}=\pi \cdot \mathrm{ER} \\
& \mathrm{PM}=\pi(1+t) \mathrm{ER}
\end{aligned}
$$

Poreign-Traded Goods Supplies

$$
\begin{aligned}
& M=\pi^{\epsilon_{\mathrm{s}}} \\
& E=\pi^{-\epsilon_{\mathrm{d}}}
\end{aligned}
$$

Determination of Premia Rates

$$
\begin{aligned}
& M<M * \neq \lambda>0: P M V=P M(1+\lambda) \\
& M=M * \neq \lambda=0 ; P M V=P M
\end{aligned}
$$

Numeraire

$$
\text { PD } \equiv 1
$$


Iable Al (continued)

\section{Veriables}

$x$

$L$

K

$v$

VII

Vo

CI

CD

E

D

Y

QR

r

L

KM

t

PM

PIY

PE

ER

\section{Dofinition of Variables and Paracotore}

Donentic output

Lobor une

Copital ueo

Intormadiate use (domentie and importad)

Importad intoraediete soode

Demostic intarnadieto goode

Importad consumption goode

Dometic consumption goods

Exports

Domestic goode for domestic use

Agaregato domentic inceme

Total teriff rovenus

Rental reto

Lobor supply

Imported capitol

Import tarifl rato

Domestic currencice price of isportad conauner and intormediate soode

QR-riddon price of consumer and Intarmadiato goode

Domeatic currency price of exported goode

Exchenge rate (In torme of numorairo)

\section{Poremetere and Exogenous Veriables}

$\bar{b}$

$\overline{\mathrm{KD}}, \overline{\mathrm{LS}}$

อ

$\sigma_{0}, \sigma_{\boldsymbol{n}}>0$

$\sigma_{\mathrm{p}}>0$

$\lambda>0$

$t>0$

$\epsilon_{0}>0$

$\epsilon_{d}>0$

$\pi \equiv \pi_{0} \equiv \pi_{0}$
Bolence of trade

Dametic capital; labor supoly

Input-output coofficient

Compenented price elesticitice of export eupoly and import demand Capital labor a betitution

Premiun rate when $Q R$ is binding

Import toriff

Import Supply Elasticity

Foreign Export Deand Elestielty

By cholce of unite. Forelon currency pries (in torme of numoreire) 
TOGle A2: SUMMARY STRUCTURE OF THE 1984 U.S. ECONOWY

\begin{tabular}{|c|c|c|c|c|c|c|c|c|c|c|c|c|}
\hline & $x$ & D & 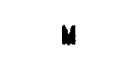 & E & $L$ & $k$ & $t_{m}$ & $\lambda$ & $\sigma_{p} 1 /$ & $\sigma_{m p}^{2} /$ & $\mathrm{po}^{3 /}$ & $E^{4} /$ \\
\hline Coluan & 1 & 2 & 3 & 4 & 5 & 6 & 7 & 8 & 9 & 10 & 11 & 12 \\
\hline Primary & 482.317 & 449.877 & 84.378 & 32.440 & 427.800 & 2449.031 & .006 & .000 &.$\infty 0$ & 1.42 & $3 . \infty 0$ & .34 \\
\hline Toxtiles & 122.804 & 118.044 & 23.623 & 6.760 & 180.000 & 64.448 & .177 & .405 & $1 . \infty$ & 2.68 & $2 . \infty 0$ & 1.30 \\
\hline Vehicle & 124.203 & 119.343 & 32.016 & 4.860 & 63.645 & 292.498 & .027 & .318 & .81 & 2.01 & $2 . \infty 0$ & 1.00 \\
\hline Stool & 57.508 & $E 6.148$ & 12.708 & 1.380 & 53.100 & 236.517 & .053 & .000 & 1.00 & 3.05 & $2 . \infty 0$ & 1.00 \\
\hline Other Tradable & 4018.182 & 3780.602 & 269.996 & 237.680 & 6000.254 & 16250.987 & .029 & .000 & .80 & .40 & $2 . \infty$ & .70 \\
\hline Mon-traded Sorvicee & 2443.322 & 2443.322 & .000 & .000 & 3768.800 & 14037.808 & .000 & .000 & .80 & 3.15 & $2 . \infty 0$ & 1.45 \\
\hline Totels & $\underline{7248.336}$ & 6908.336 & $\$ 103.319$ & $\underline{283.000}$ & 10500.599 & 32322.277 & & & & & & \\
\hline
\end{tabular}

Note: All velues in columns 1 to 6 ore in 1984 sillion. For o definition of veriables, sec Table Al.

1) Elesticity of ubatitution in production.

2) Compenested price elesticity of import demand.

3/ Compenseted price elesticity of export supply.

If Incoms olesticity of demand. 
PRE Working Paper Series

Itte

WPS496 Issues in Evaluating Tax and Payment Arrangements for Publicly Owned Minerals

WPS497 The Measurement of Budgetary Operations in Highly Distorted Econumies: The Case of Angola

WPS498 The Build, Operate, and Transler ("BOT") Approach to Infrastructure Projects in Developing Countries

WPS499 Taxing Foreign Income in CapitalImporting Countries: Thailand's Perspective

WPS500 Projecting Fertility for All Countries

WPS501 Tax Systems in the Reforming Socialist Economies of Europe

WPS502 Patents and Pharmaceutical Drugs: Understanding the Pressures on Developing Countries

WPS503 Household Production, Time Allocation, and Welfare in Peru

WPS504 Applying Tax Policy Models in Country Economic Work: Bangladesh, China, and India

WPS505 Creating the Reform-Resistant Dependent Economy: The CMEA International Trading Relationship

WPS506 Changes in Food Consumption Patterns in the Republic of Korea

WPS507 Poverty in Poland, Hungary, and Yugoslavia in the Years of Crisis. 1978-87

WPS508 A RMSM-X Model for Chile

WPS509 The Childbearing Family in Sub-Saharan Africa: Structure, Fertility, and the Future
Auther

Robert Conrad

Zmarak Shalizi

Janet Syme

Carlos Elbirt

Mark Augenblick

B. Scott Custer, Jr.

Chad Leechor Jack M. Mintz

Date

Contact

for paper

August 1990

A. Bhalla 37699

August 1990

T. Gean

34247

August 1990

D. Schein 70291

September 1990

A. Bhalla 37699

Eduard Bos

Rodolfo A. Bulatao

September 1990 V. Altfeld 31091

C. :eryl W. Gray

September 1990

L. Lockyear 36969

September 1990

M. T. Sanchez 33731

John Dagsvik

Rolf Aaberge

Henrik Dahl

Pradeep Mitra

September 1990

A. Bhalla 37699

Arye L. Hillman Adi Schnytzer

September 1990

CECSE Staff 37176

Merlinda D. Ingco

Branko Milanovic

September 1990

A. Bretana 37176

Luis Serven

September 1990

S. Jonnakuty 39074

Odile Frank

September 1990

B. Rosa 33751
A. Daruwala 33713 


\section{PRE Working Paper Series}

Iite

WPS510 Public Expenditure Reviews for Education: The Bank's Experience

WPS511 The Macroeconomic Underpinnings of Adjustment Lending

WPS512 Social Security Reform: The Capital Accumulation and Intergenerational Distribution Effect

WPS513 The Business Cycle Associated with Exchange-Rate-Based Stabilization

WPS514 Restrictive Labor Practices in Seaports

WPS515 Stock Markets in Developing Countries: Key issues and a Research Agenda

WPS516 International Capital Mobility and the Costs of U.S. Import Restraints

WPS517 Do Wage Distortions Justify Protection in the U.S. Auto and Steel Industries?

WPS518 Industrial Organization and Trade Liberalization: Evidence from Korea
Auther

Date

Contact

terpaper

Antoine Schwartz

Gail Sievenson

Fred Jaspersen

Karim Shariíf

Patricio Arrau

Miguel A. Kiguel

Nissan Liviatan

Alan S. Harding

Mansoor Dailami

Michael Atkin

Jaime de Melo

David Roland-Holst

Jaime de Melo

David Tarr

Jaime de Melo

David Roland-Holst
Octaber 1990

C. Cristobal 33640

October 1990

A. Oropesa 39075

October 1990

S. King-Watson 31047

October 1990

E. Khine 39361

Cotober 1990

A. Joseph 33743

October 1990

M. Raggambi 37657

October 1990

S. Fallon 37947

October 1990

S. Fallon 37947

October 1990

S. Fallon 37947 